\title{
A perspective on stem cells by a clinician
}

\author{
Ieuan A Hughes \\ Department of Paediatrics, University of Cambridge, Box 116, Level 8, Addenbrooke's Hospital, Hills Road, Cambridge CB2 $20 Q$, UK \\ (Correspondence should be addressed to I A Hughes; Email: iah1000@cam.ac.uk)
}

\begin{abstract}
Stem cell terminology has entered the lexicon of medical practitioners even though the application of harvesting stem cells to treat diseases other than haematological disorders is not yet a reality in clinical practice. All branches of medicine will be affected by the new technology, more so those related to regenerative cell-based therapy for disorders such as Parkinson's disease, Alzheimer's disease, multiple sclerosis and traumatic injuries to the nervous system. Endocrinology is not a branch of medicine that carries a burden of disease that merits priority for the early application of stem cell therapy once the technique becomes safe and practical to do so. However, the allied disorder of diabetes is, sine qua non, an ideal example of how stem cell therapy has the potential to cure a chronic disabling condition. It is logical therefore to have included a number of articles on stem cells in this special issue of this journal, publishing papers on a range of endocrine-related topics.
\end{abstract}

European Journal of Endocrinology 151 U3-U5

\section{Biology of stem cells}

The literature is replete with volumes of original papers and review articles on stem cells, including a major tome on the subject (1). The terminology that clinicians now need to learn include pluripotent versus multipotent, dedifferentiation versus transdifferentiation, plasticity and nuclear transfer, to give just a few examples. A factor of overwhelming importance in this field of research relates to the advantages and disadvantages of embryonic stem cells versus adult (somatic) stem cells (2).

It was only a couple of decades ago that embryonic stem cells were successfully harvested from mouse embryos, and just 6 years ago that the techniques were successfully applied in human embryos derived from in vitro fertilisation (IVF) programmes (3, 4). The principles of the techniques are remarkably simple (see Fig. 1, (5)), but this should not belie the ongoing challenges faced by scientists in devising culture conditions that enhance the yield of stem cells without risking the transfer of pathogens, induction of genomic instability and immuno-intolerance. In order to isolate the inner cell mass, from which embryonic cells are derived, pre-implantation embryos are cultured to the blastocyst stage, which is about 5-7 days after fertilisation. Propagation of these cells continues only on a feeder layer of fibroblasts that are murine in origin. It is this dependency that has led to concerns about inter-species transfer of organisms. This obstacle should be overcome in due course if preliminary results using human foreskin feeder cell lines to successfully culture embryonic stem cells are confirmed (6). The growth rate of embryonic stem cells is relatively slow, so recent developments in manipulating the culture conditions to shorten the cell line doubling times will enhance the yield for experimental studies and, eventually, for cell-based therapy (7). There are many facets to the science of producing human stem cell lines which, on the one hand, can maintain their undifferentiated state for unlimited self-renewal and, on the other, need to be manipulated in order to direct the cells towards a specific lineage. Readers who are interested to know more about the emerging techniques that are realising these aims are referred to an excellent review by Stojkovic et al. (8).

A milestone in stem cell research was recently achieved with the successful establishment of a human embryonic stem cell line from blastocysts that were derived from embryos created by somatic cell nuclear transfer (9). This human equivalent of the 'Dolly the sheep' experiment is a pivotal step forward in realising the benefits of therapeutic cloning. Now it will be possible to produce pluripotent stem cells to incorporate the nuclear genome of the patient and induce these undifferentiated cells to adopt a particular lineage for transplanting back to the patient, thus avoiding immune rejection (10). Studies with animals and using human tissues are already demonstrating the success of this technique in multiple organ systems of the body.

\section{Clinical applications}

The only potential clinical application of stem cell therapy of direct relevance to this journal issue and its readers, is the generation of stem cells with the 


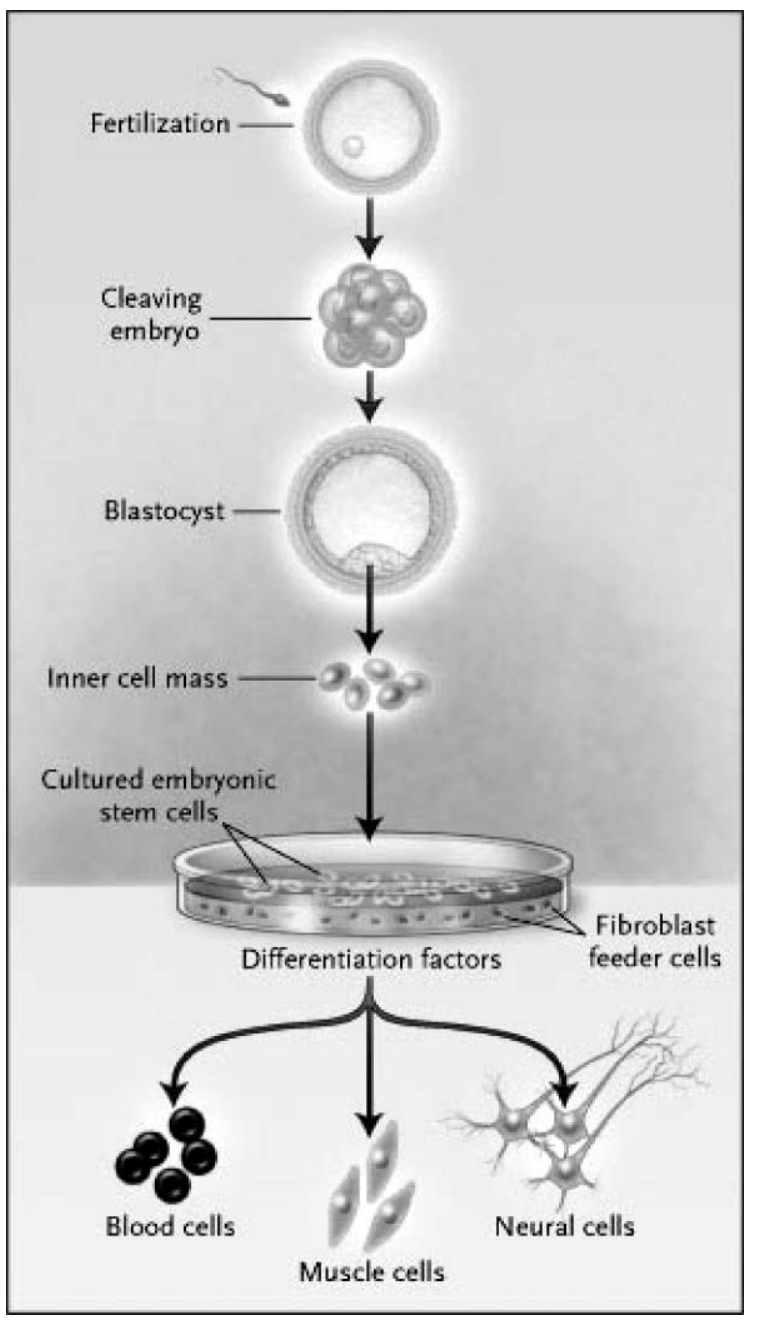

Figure 1 Derivation of embryonic stem cells. (Reproduced from (5) with permission from Massachusetts Medical Society, Copyright 2004.)

characteristics of pancreatic beta-cells and insulin production (11). The autoimmune destruction of beta-cells that defines the insulin-dependence of Type 1 diabetes implies that insulin replacement in some form is the only treatment option for the foreseeable future. Prevention strategies are certainly possible but do not yet appear to be making their mark in clinical practice. Islet cell transplantation has shown impressive results in highly selected patients with serious control problems and disease complications (12). A limited supply of cells and the continuing need for immunosuppression highlights the potential benefits of inducing embryonic or adult stem cells to differentiate as insulin secreting beta-cells (13). This is where adult stem cells, derived from the pancreas itself, would be particularly advantageous if the resources could be successfully manipulated for therapeutic cloning. Such islet cell neogenesis may arise from pancreatic ductal cells, but there may also be other sources, such as the exocrine cells. A word of caution should be applied to defining the characteristics of an insulin-secreting cell. Doubt has been expressed that insulin immunoreactivity in embryonic stem cell cultures may just be reflecting insulin uptake from the culture medium rather than insulin synthesis de novo (14). Nonetheless, progress is being made by demonstrating that transplantation of rodent embryonic stem cells, differentiated to produce insulin, can reverse diabetes, and new human embryonic cell lines are being developed that may better replicate the function of the 'natural' beta-cell (15).

No other area of endocrine practice springs to mind as a target for stem cell therapy. However, once the technology is developed for safe cell-based regenerative therapy, a number of endocrine disorders could be treated in this manner. Much of endocrine treatment is based on hormone replacement strategies and many, such as thyroxine treatment for hypothyroidism, are straightforward. Perhaps glucocorticoid replacement regimes are more complex, and would there be a place one day for stem cell therapy to treat congenital adrenal hyperplasia? Even the ability to derive gametes from embryonic stem cells may not render replacement therapy with these specialised cells off the endocrine agenda in the future (16).

\section{Ethics and politics}

The ethical issues surrounding stem cell therapy are complex, and two articles in this issue have covered various aspects in considerable detail from almost a philosophical perspective $(17,18)$. In simple terms, the crux of the question appears to be whether one believes that the zygote at fertilisation is a human-person or is just biologically a human. There is no definitive answer to a question which comes down to personal beliefs. The extraction of the inner cell mass at the blastocyst stage, and thereby separating it from the zona pellucida (a technique referred to as 'immunosurgery'), renders the embryo as unviable. Some believe this is tantamount to destruction of a human embryo, a procedure followed constantly with 'spare' embryos in IVF work. A useful analogy was proposed recently by Sandel (19), in which the author refers to the fact that not all acorns develop into oak trees even though every oak tree was once an acorn. The felling of an oak tree as a result of a storm is not the same as having lost an acorn strewn on the lawn from animal predators.

A clear distinction is expressed by scientists and politicians alike between stem cell research for the purpose of therapeutic cloning (and understanding the biology of cell differentiation) and that for the purpose of reproductive cloning. Legal safeguards against the latter activity developing is now in place in many countries. What has not been resolved in any uniform manner is the generation of embryos in short-term culture for the purpose of deriving stem cells for therapeutic 
purposes, including using the somatic cell nuclear transfer technique. Licences are now being granted to recognised laboratories in the UK for this purpose. In mainland Europe, there is a ban on such work in Norway and Germany, whereas the use of fertilised eggs as a source of stem cells is accepted in Sweden, The Netherlands and France (20). Nowhere are views more polarised on the subject than in the USA, where President Bush decreed that government funding for stem cell research would only be permitted on cell lines established before August 2001. The matter was of sufficient importance as to contribute to the outcome of the 2004 Presidential election.

To overcome this constraint on stem cell research, a coalition of scientists and business people in California plan to raise funds, which are independent of organisations like the NIH, to enable competitive, peer-reviewed grants to be awarded to researchers working on stem cells (21). In parallel, industry has a major vested interest in seeing the benefits of stem cell research, and companies are already being formed to produce the larger quantities of stem cells that will be needed when clinical medicine properly enters the era of regenerative medicine (22). However, a word of caution should be sounded as to whether the 'hype' surrounding stem cell technology is akin to the myth being promulgated about the output from a medicinal 'biotech revolution' not keeping pace with the amount of research and development being invested (23).

\section{References}

1 Lanza R, Gearhart J, Hogan B, Melton D, Pedersen R, Thomson J \& West M, Eds. Handbook of Stem Cells Amsterdam: Elsevier Academic Press, 2004.

2 Hassan HT \& El-Sheemy M. Adult bone-marrow stem cells and their potential in medicine. Journal of the Royal Society of Medicine $200497465-471$.

3 Evans MJ \& Kaufman MH. Establishment in culture of pluripotential cells from mouse embryos. Nature 1981292 154-156.

4 Thompson JA, Itskovitz-Eldor J, Shapiro SS, Waknitz MA, Swiergiel JJ, Marshall VS \& Jones JM. Embryonic stem cell lines derived from human blastocysts. Science $1998 \mathbf{2 8 3} 1145-1147$.

5 Gearhart J. New human embryonic stem-cell lines - more is better. New England Journal of Medicine $20043 \mathbf{5 0} 1275-1276$.

6 Choo AB, Padmanabhan J, Chin AC \& Oh SK. Expansion of pluripotent human embryonic stem cells on human feeders. Biotechnology Bioengineering 200488 321-331.
7 Cowan CA, Klimanskaya I, McMahon J, Atienza J, Witmyer J, Zucker JP, Wang S, Morton CC, McMahon AP, Powers D \& Melton DA. Derivation of embryonic stem-cell lines from human blastocysts. New England Journal of Medicine $2004 \mathbf{3 5 0}$ $1353-1356$

8 Stojkovic M, Lako M, Strachan T \& Murdoch A. Derivation, growth and applications of human embryonic stem cells. Reproduction $2004128259-267$.

9 Hwang WS, Ryu YJ, Park ES, Lee EG, Koo JM, Jeon HY, Lee BC, Kang SK, Kim SJ, Ahn C, Hwang JH, Park KY, Cibelli JB \& Moon SY. Evidence of a pluripotent human embryonic stem cell line derived from a cloned blastocyst. Science $2004 \mathbf{3 0 3}$ $1669-1674$.

10 Gerecht-Nir S \& Itskovitz-Eldor J. Cell therapy using human embryonic stem cells. Transplant Immunology 200412 203-209.

11 Assady S, Maor G, Amit M, Itskovitz-Eldor J, Skorecki KL \& Tzukerman M. Insulin production by human embryonic stem cells. Diabetes 200150 1691-1697.

12 Robertson RP. Islet transplantation as a treatment for diabetes - a work in progress. New England Journal of Medicine 2004350 694-705.

13 Street CN, Sipione S, Helms L, Binette T, Rajotte RV, Bleackley RC \& Korbutt GS. Stem cell-based approaches to solving the problem of tissue supply for islet transplantation in type 1 diabetes. International Journal of Biochemistry and Cell Biology 200436 667-683.

14 Rajagopal J, Anderson WJ, Kume S, Martinez OI \& Melton DA. Insulin staining of ES cell progeny from insulin uptake. Science 2003299363.

15 Hussain MA \& Theise ND. Stem-cell therapy for diabetes mellitus. Lancet $2004364203-205$.

16 Geijsen N, Horoschak M, Kim K, Gribnau J, Eggan K \& Daley GQ. Derivation of embryonic germ cells and male gametes from embryonic stem cells. Nature $2004 \mathbf{4 2 7} 106-107$.

17 van Leeuwen E. On the origin, use and destination of human embryos. European Journal of Endocrinolgy 2004151 (Suppl) U11-U14.

18 Alonso C. An ontological view of the human embryo. A paradigm. European Journal of Endocrinolgy 2004151 (Suppl) U15-U22.

19 Sandel MJ. Embryo ethics - the moral logic of stem-cell research. New England Journal of Medicine $2004351207-209$.

20 Evers K. European Perspectives on Therapeutic Cloning. New England Journal of Medicine 2002346 1579-1582.

21 Yamamoto KR. Bankrolling stem-cell research with California dollars. New England Journal of Medicine $20043511711-1713$.

22 Spar D. The business of stem cells. New England Journal of Medicine $2004351211-213$.

23 Nightingale P \& Martin P. The myth of the biotech revolution. Trends in Biotechnology 200422 564-569.

Received 28 October 2004

Accepted 3 November 2004 